\title{
Knowledge, attitudes and peer influences related to pregnancy, sexual and reproductive health among adolescents using maternal health services in Ugu, KwaZulu-Natal, South Africa
}

\author{
Desiree Govender ${ }^{1,2,3^{*}}$ (D), Saloshni Naidoo ${ }^{2}$ and Myra Taylor ${ }^{2}$
}

\begin{abstract}
Background: Knowledge and practices of sexual and reproductive healthcare is pivotal to the Safe Motherhood Initiative; however, only a few studies have investigated adolescent mothers' knowledge of sexual and reproductive health in light of the above initiative. Research should thus focus on the knowledge and attitudes of adolescent girls as well as peer influences related to pregnancy and sexual and reproductive health among adolescents, as the findings may highlight vital health interventions that should be introduced. The aim of this study was thus to determine the knowledge, personal attitudes and peer influences related to pregnancy, sexual and reproductive health among adolescents who attended maternal health services in a district hospital in Ugu, KwaZulu-Natal, South Africa.
\end{abstract}

Methods: A cross sectional study was conducted. Data were collected from 326 adolescents who accessed maternal health services in a peri-urban district hospital during June 2017 and November 2017. The questionnaire surveyed the knowledge, personal attitudes and peer influences related to pregnancy, sexual and reproductive health. The questionnaire was administered by fieldworkers using mobile devices powered by the Mobenzi Researcher ${ }^{\circledR}$ technology. The completed surveys were uploaded to the Mobenzi server where it was stored and aggregated. The data was analysed using R software.

Results: Of the 326 participants, 65 (19.9\%) experienced repeat pregnancies in adolescence. Overall, only 143 (43.9\%) of the participants answered $50 \%$ or more of the knowledge questions on pregnancy and HIV/AIDS and STIs correctly, while 183 (56.1\%) answered less than 50\% of the knowledge questions correctly. There was no relationship between knowledge of pregnancy and HIV/STIs and repeat adolescent pregnancies.

Conclusion: Adolescents' knowledge of pregnancy and sexual and reproductive health was deficient as, even with repeat pregnancies, these adolescents were evidently no better informed about pregnancy and sexual and reproductive health. This suggests that social determinants, modes and platforms regarding the delivery of adolescent sexual and reproductive health education are important. An innovative mode to the delivery of sexual and reproductive health education includes the emerging digital platform. The digital platform encompasses social media, multimedia and mobile phones which is growing popular among young people.

Keywords: Adolescent pregnancy, HIV, Sexually transmitted infections, Safe motherhood initiative, Sexual and reproductive health

\footnotetext{
* Correspondence: desireegovender19@gmail.com

${ }^{1}$ KwaZulu-Natal Department of Health, Durban, South Africa

${ }^{2}$ School of Nursing and Public Health, Discipline of Public Health Medicine,

University of KwaZulu-Natal, Durban, South Africa

Full list of author information is available at the end of the article
}

C) The Author(s). 2019 Open Access This article is distributed under the terms of the Creative Commons Attribution 4.0 International License (http://creativecommons.org/licenses/by/4.0/), which permits unrestricted use, distribution, and reproduction in any medium, provided you give appropriate credit to the original author(s) and the source, provide a link to the Creative Commons license, and indicate if changes were made. The Creative Commons Public Domain Dedication waiver (http://creativecommons.org/publicdomain/zero/1.0/) applies to the data made available in this article, unless otherwise stated. 


\section{Background}

Adolescence is a complex stage in life that is characterised by conflicts among responsibilities, independence and experimentation [1], and health and social problems may be extensive during this phase [2]. According to the World Health Organization, the main health issues among adolescents include early pregnancy, childbirth, HIV/AIDS, depression, violence, alcohol and drug abuse, intentional injuries, malnutrition, obesity, and tobacco use [3]. Adolescents account for 1.2 billion people globally and $11 \%$ of all births worldwide are to girls aged $15-19$ years [4]. South Africa is home to approximately 9.68 million adolescents [5] and the adolescent pregnancy rate here is 47 births per 1000 females aged 15-19 per annum [6]. Adolescent pregnancy and childbearing is increasingly recognised as a serious, worldwide public health concern. The maternal mortality rate associated with pregnant adolescents has been attributed to pregnancy induced hypertension, HIV/AIDS, Tuberculosis, obstetric haemorrhaging, and medical and surgical disorders $[6,7]$. The HIV prevalence in South Africa is estimated at $13.1 \%$ [5].

Sexual and reproductive health (SRH) programs are often not prioritised due to a lack of funding and the emphasis that is placed on community-based HIV prevention programmes [8]. There are also restrictive laws and policies concerning adolescent sexual and reproductive health [9]. Access to SRH in the Asia Pacific Region is dependent on age and the regulation of marital status [10, 11]. Customary and religious laws require persons under the age of 18 years to seek consent from parents or spouses to access SRH [10]. Healthcare providers may also be prohibited from delivering contraceptive services to unmarried persons [11]. The age that an adolescent is allowed to consent for sex often conflicts with the age that the adolescent is allowed to consent for medical interventions [10]. Thus, the blatant disregard of adolescent SRH often results in a damaging transition to adulthood [9]. Education and clinical services, which are the cornerstones of SRH, are essential in promoting positive sexual development and decreasing adverse social, economic and health outcomes associated with sexual behaviour [12]. Parents, teachers, healthcare providers and community leaders are the gatekeepers of adolescent sexual and reproductive health because they are responsible sources of SRH information and services for adolescents [13].

The Safe Motherhood Initiative was a key outcome of the first international Safe Motherhood Conference in Nairobi, Kenya, in 1987 [14]. The pillars of the Safe Motherhood Initiative include family planning, antenatal care, obstetric care, postnatal care, post abortion care and STI/HIV/AIDS control. The Safe Motherhood Initiative is founded on the principle of sound knowledge and practices of reproductive health; however, only a few studies have investigated adolescent mothers' knowledge of sexual and reproductive health [14]. Universal access to SRH services is one of the specific targets of the Sustainable Development Goals pertaining to health (SDG3) [15]. Thus knowledge, personal attitude and peer influences can influence adolescents' decision to access maternal, sexual and reproductive health services or not. However, far too little attention has been paid to the knowledge, personal attitudes and peer influences related to pregnancy, sexual and reproductive health among adolescent girls accessing maternal health services.

A lack of pregnancy related knowledge among pregnant adolescent girls can adversely affect their lives as well as those of their unborn children [16]. Therefore, adolescent pregnant women should be equipped with knowledge so that they will be able to engage in good health practices during pregnancy. They should also identify danger signs during pregnancy and make prompt decisions about appropriate care and support. The age and maturity level of pregnant women may impact their susceptibility to antenatal education and their ability to identify danger signs associated with their pregnancy [17]. However, knowledge of SRH and pregnancy among adolescents has remained inadequate [4], and therefore adolescent pregnancy is considered a high health risk as poor nutrition, limited knowledge, and ignorance of danger signs during pregnancy can be devastating.

This paper is an excerpt from a larger doctoral study that aims to develop a community of practice model for a multidisciplinary and comprehensive approach towards caring for pregnant and parenting adolescent mothers. This doctoral study is being conducted in Ugu, KwaZuluNatal, South Africa. The purpose of this paper is to report the knowledge, personal attitudes and peer influences related to pregnancy, sexual and reproductive health among adolescents who utilised maternal health services in a district hospital in Ugu, KwaZulu-Natal, South Africa.

\section{Methods \\ Study design and setting}

A descriptive cross-sectional study design was used to assess the knowledge, attitudes and peer influences related to pregnancy, sexual and reproductive health among adolescents using maternal health services in the study site during June 2017 to November 2017. The target sample size of 326 participants were reached for the study. The study was conducted in a district hospital in Ugu, KwaZulu Natal. At the time of the study, the majority of the study population $(84 \%)$ resided in rural areas whereas only $16 \%$ resided in the urban coastal strip. Generally, KwaZulu-Natal has the highest prevalence of HIV in pregnant women (44.4, 95\% CI: 42.5-46.3\%) among the South African provinces [18]. According to the South African 
National Antenatal Sentinel HIV and Syphilis Prevalence Survey, HIV prevalence is $45.9 \%$ in the Ugu district [18].

\section{Study population and sampling}

The study population included adolescent girls aged 13-19 years manifesting first and repeat pregnancies and accessing the maternal health services at the district hospital. Convenience sampling was used to recruit these females. Adolescents with first and repeat pregnancies who attended the ante- and postnatal clinics were identified by the nurses and briefly informed about the study. The nursing staff was aware of the inclusion and exclusion criteria, which included the adolescents' cognitive abilities, and they recruited participants accordingly. The nursing staff used the questions from the modified mini mental state exam (MMSE) to determine the participants cognitive function. The MMSE is a widely used measure of global cognitive function [19]. The questions in the MMSE with regards to the tests of orientation (time, place, person), registration and recall are used in the assessment of the maternity healthcare users at the institution. Interested participants were referred to the research assistants stationed in the clinic who then provided them with more details, after which they decided whether to participate voluntarily or not.

The sample size of 326 participants were determined for the study on the prevalence of adolescent repeat pregnancy at the study site. Details of the sample size calculation for the prevalence study has been described elsewhere. The eligibility criteria for participants were: 1) pregnant and postpartum adolescent girls aged 13-19 years, and 2) pregnant and postpartum adolescents under 18 years (but above 13 years) who had obtained permission from their parent/s or legal guardian/s to participate in the study. The exclusion criteria included: 1) pregnant and postpartum adolescents under 13 years of age; 2) pregnant and postpartum adolescents under 18 years of age who had not obtained permission from their parent/s or legal guardians to participate in the study; and 3) pregnant and postpartum adolescents with cognitive impairment. Parental or legal guardian consent for participants under the age of 18 years was stipulated by the Biomedical Research Ethics Committee, UKZN.

\section{Measurement instrument}

The Healthy Pregnancy Knowledge Survey (HPKS) questionnaire, which was developed by Godin et al. [20], was adapted for this study to measure the participants' knowledge related to pregnancy health. The HPKS questionnaire contained 25 questions relating to three major topics: healthy pregnancy, a healthy lifestyle, and breastfeeding. The questionnaire was originally piloted in thirty public health institutions in Ontario. Although the validity and reliability of the HPKS were not formally assessed, professionals and academics in the fields of public health and maternal and child health gave relevant and comprehensive input for the development of the HPKS. The questionnaire contained multiple choice questions and a 'true' and 'false' scale with a 'do not know' option. Knowledge and practices of sexual and reproductive healthcare included questions on: 1) HIV/AIDS and STIs; 2) sexual risk behaviour and prevention; 3) personal attitudes towards sexuality and reproduction; and 4) peer influences.

The questionnaire also included questions about topics that were taught in the Life Orientation curriculum at school (Additional file 1). A Life Skills programme was introduced in secondary schools in South Africa in 1996 to provide learners with comprehensive information on HIV/AIDS and STIs, reproduction, contraception, pregnancy, violence, decision making and sexual negotiation [21]. This programme has now been integrated into the Life Orientation curriculum. Life Orientation is a standardised subject in school that focuses on topics such as teenage pregnancy, contraception, STIs, HIV/AIDS, sexuality, and reproduction.

The South African Department of Basic Education [22] describes Life Orientation as "the study of the self in relation to others and to society. It addresses skills, knowledge and values about the self, the environment, responsible citizenship, a healthy and productive life, social engagement, recreation and physical activity, careers and career choices" (p.8). Life Orientation is an essential subject required for the National Senior Certificate and is thus a compulsory subject for all learners in Grades 10, 11 and 12 in South Africa.

The questionnaire was piloted among 25 pregnant adolescents by fieldworkers using mobile devices powered by Mobenzi Researcher ${ }^{\oplus}$ technology. The study site was the antenatal unit at the hospital where the current doctoral study is conducted. The aim of a pilot study was to establish the user friendliness of the questionnaire. A gynaecologist, a clinical midwife, a school health manager, a clinical psychologist and an adolescent and reproductive academic expert were consulted to establish the face and content validity of the questionnaire.

\section{Data collection}

Fieldworkers were recruited from the local community and received training on research ethics, the aims and objectives of the study, and mobile data collection. The questionnaire survey (measurement instrument) was administered by the fieldworkers using mobile cellular tablets powered by the Mobenzi Researcher technology. The responses to the survey were obtained in mobile assisted face-to-face interviews between the fieldworkers and individual female adolescents. The interviews were conducted in safe, private settings within the ante- and postnatal units. Mobenzi Researcher, which was developed in 2008 in 
South Africa, is a platform for the mobile collection of baseline data. The software was installed on the handsets. The mobile application technology supports various question types and also allows for the marking of fields as 'mandatory' and 'not applicable'. The completed surveys were uploaded to the Mobenzi survey where they were stored and aggregated.

\section{Data analysis}

The data from the research console were cleaned and exported into $\mathrm{R}$ software ( $\mathrm{R}$ version 3.5.0. Vienna: R Foundation for Statistical Computing) for statistical analyses. Frequency distributions and summary statistics were used to describe the data. The percentage of adolescent girls who were able to answer $50 \%$ of the questions about pregnancy and HIV/AIDS/STI knowledge correctly was determined. A study conducted in Malaysia had used 50\% as a cut-off score for reasonable knowledge of pregnancy and sexual and reproductive health [16]. The Fisher's exact test was used to ascertain statistical significance of categorical variables while the Wilcoxon signed ranked test was used to perform comparisons between continuous variables. A univariate logistic regression model was constructed with adolescent repeat pregnancy as the outcome variable of interest. The main exposure of interest was whether or not the adolescent girls answered $50 \%$ of the pregnancy and HIV/AIDS/STI related questions correctly. A multivariate logistic regression model was created similar to the univariate logistic regression model, but it adjusted for age, education levels, and the mothers' marital status. A $p$-value of 0.05 was considered statistically significant.

\section{Results}

Socio-demographic, obstetric, clinical characteristics and knowledge survey results

A total of 326 participants completed the questionnaire. The majority of the participants was in the age group $17-19$ years $(86.5 \%, n=282)$. Of the 326 participants, 98.5\% was single (Table 1). All the participants indicated that they had received formal education while 51.5\% $(n=168)$ indicated that their biological mothers had received formal education. Most of the participants $(97.5 \%, n=318)$ were unemployed. Only $102(31.0 \%)$ of the participants indicated that their biological mothers were married, while 147 (45.1\%) stated that their biological mothers were single.

Of the 326 participants, 65 (19.9\%) had experienced repeat pregnancies during their adolescent years and 28 $(8.6 \%)$ of the participants admitted that they had experienced a spontaneous abortion. The clinical histories revealed that $23(7.1 \%)$ of the participants had experienced pregnancy induced hypertension while 25 (7.7\%) had experienced anaemia. The prevalence of HIV among the participants was $17.8 \%(n=58)$.
Table 1 Socio-demographic, obstetric, clinical characteristics and knowledge survey results $(n=326)$

\begin{tabular}{|c|c|c|}
\hline Variables & Frequencies (n) & Percentages (\%) \\
\hline \multicolumn{3}{|l|}{ Age } \\
\hline $14-16$ & 44 & $13.5 \%$ \\
\hline $17-19$ & 282 & $86.5 \%$ \\
\hline \multicolumn{3}{|l|}{ Marital status of participants } \\
\hline Single & 321 & $98.5 \%$ \\
\hline Married & 5 & $1.5 \%$ \\
\hline \multicolumn{3}{|l|}{ Highest educational level } \\
\hline Primary & 9 & $2.8 \%$ \\
\hline Junior & 12 & $3.7 \%$ \\
\hline Secondary & 305 & $93.6 \%$ \\
\hline \multicolumn{3}{|l|}{ Employment status of participants } \\
\hline Employed full time & 6 & $1.8 \%$ \\
\hline Employed part time & 2 & $0.6 \%$ \\
\hline Unemployed & 318 & $97.5 \%$ \\
\hline \multicolumn{3}{|l|}{ Family characteristics } \\
\hline \multicolumn{3}{|l|}{ Biological mother's marital status } \\
\hline Single & 147 & $45.1 \%$ \\
\hline Married & 101 & $31 \%$ \\
\hline Other & 78 & $23.9 \%$ \\
\hline \multicolumn{3}{|l|}{ Educational level of biological mother } \\
\hline Primary school & 29 & $8.9 \%$ \\
\hline Junior secondary & 17 & $5.2 \%$ \\
\hline Senior secondary & 118 & $35.6 \%$ \\
\hline Technical school & 3 & $0.9 \%$ \\
\hline University degree & 3 & $0.9 \%$ \\
\hline None & 28 & $8.6 \%$ \\
\hline Do not know & 130 & $39.9 \%$ \\
\hline \multicolumn{3}{|l|}{ Obstetric history } \\
\hline \multicolumn{3}{|l|}{ Had an adolescent repeat pregnancy? } \\
\hline No & 261 & $80.1 \%$ \\
\hline Yes & 65 & $19.9 \%$ \\
\hline \multicolumn{3}{|l|}{ Number of spontaneous abortions } \\
\hline 0 & 298 & $91.4 \%$ \\
\hline 1 & 27 & $8.3 \%$ \\
\hline 2 & 1 & $0.3 \%$ \\
\hline \multicolumn{3}{|l|}{ Medical conditions } \\
\hline High blood pressure & 23 & $7.1 \%$ \\
\hline Anaemia & 25 & $7.7 \%$ \\
\hline HIV & 58 & 17.8 \\
\hline \multicolumn{3}{|c|}{$\begin{array}{l}\text { Answered knowledge questions } \\
\text { correctly (Pregnancy, HIV/AIDS and STIs) }\end{array}$} \\
\hline $50 \%$ or more questions correct & 143 & $43.9 \%$ \\
\hline Less than $50 \%$ correct & 183 & $56.1 \%$ \\
\hline
\end{tabular}




\section{Life orientation}

The participants were asked if HIV/AIDS, STIs, contraception, menstruation, male circumcision, teenage pregnancy, termination of pregnancy, abuse, depression and anxiety were covered in the Life Orientation curriculum when they attended school. Of the 326 participants, 129 (39.6\%) stated that contraception was not covered in Life Orientation. Furthermore, 154 (47.2\%) had not learnt about the termination of pregnancy in Life Orientation. Most participants, 77.9 and $72.9 \%$ respectively, stated that HIV/AIDS and STIs was covered in Life Orientation. When asked about adolescent pregnancy, 286 $(87.7 \%)$ reported that this topic was covered in Life Orientation while only 164 (50.3\%) reported that depression and anxiety were covered in the Life Orientation curriculum at school.

\section{Miscellaneous general pregnancy and signs of preterm labour knowledge}

A total of $303(92.9 \%)$ correctly identified that a pregnant woman must consult her clinician (doctor or midwife/ nurse) should she feel unwell, has a fever, and/or experiences an unusual physical change (Table 2). Less than half of the participants $(44.2 \%, n=144)$ was able to correctly identify the advice that pregnant women should follow to decrease the risk of preterm labour. Only 116 (35.6\%) knew that folic acid is essential for the baby's brain and spine development. The most commonly identified signs of preterm labour were understood as cramps and abdominal pain $(48.8 \%, n=159)$, the release of fluid or blood from the vagina $(60.4 \%, n=197)$, and regular or frequent contractions or changes in the severity or number of contractions $(33.7 \%, n=110)$ (Table 2). When questioned about what a pregnant woman should do in the event of preterm labour, most participants were able to correctly identify that a pregnant woman should contact the doctor $(87.7 \%, n=286)$ or go to the hospital immediately $(94.2 \%, n=307)$.

\section{Normal symptoms during pregnancy}

A total of 235 (72.1\%) correctly identified that aches in the hips and back are a normal symptom during pregnancy. The results showed that 19 (5.8\%) of the participants did not know that nausea was experienced during pregnancy. Only $143(43.9 \%)$ and 76 (23.3\%) correctly identified that an abnormal vaginal discharge and spotted vision were abnormal symptoms during pregnancy respectively.

\section{Knowledge of anaemia}

Most participants $(63.2 \%, n=206)$ did not know that iron deficiency leads to anaemia. Less than half $(43.3 \%$, $n=141$ ) of the participants knew that anaemia can result in preterm delivery and low birth weight. When asked to identify the signs and symptoms of anaemia, only 15 (4.6\%) were able to identify six out of thirteen signs and symptoms of anaemia. The majority of the participants $(59.5 \%, n=194)$ was able to identify only one out of thirteen signs and symptoms of anaemia. The most commonly identified signs and symptoms of anaemia were pale skin $(46.3 \%, n=151)$, pale lips $(31.3 \%, n=102)$ and pale underside of the eyelids $(31 \%, n=101)$.

\section{Knowledge of alcohol and tobacco use during pregnancy} When assessing knowledge of alcohol use during pregnancy, most of the participants $(92.5 \%, n=302)$ knew that no quantity of alcohol is safe during pregnancy (Table 3). Only $64(19.6 \%)$ and 67 (20.6\%) agreed that alcohol consumption results in low birth weight and heart defects respectively. Of the 326 participants, 209 (64.1\%) knew that alcohol consumption can cause mental retardation in the unborn child. Few participants knew that tobacco use during pregnancy results in low birth weight $(22.4 \%, n=73)$, spontaneous abortion $(16.6 \%, n=54)$, preterm labour $(6.7 \%, n=22)$, and foetal deformities in the uterus $(16 \%, \mathrm{n}-52)$.

\section{Knowledge of activities that should be avoided during pregnancy}

Less than half of the participants $(42.9 \%, n=140)$ knew that the use of pesticides should be avoided during pregnancy. Only $41.1 \%$ (134) agreed that playing with cats is dangerous and 37\% (121) knew that cleaning a cat's litter box should be avoided during pregnancy. Only 20 (6.1\%) of the participants knew that X-rays should be avoided during pregnancy.

\section{Knowledge regarding breastfeeding}

Most participants $(71.8 \%, n=234)$ identified that 6 months is the recommended length of time for exclusive breastfeeding (Table 4). When assessing their knowledge about the benefits of breastfeeding, most participants correctly agreed that breast feeding improves the immunity of babies $(78.8 \%, n=257)$, decreases the risk of obesity and diabetes $(58.3 \%, n=190)$, and that breastfed babies have fewer dental cavities $(59.2 \%, n=193)$. Furthermore, 200 (61.3\%) knew that drugs and alcohol pass through breast milk.

\section{Knowledge of HIV/AIDS and STIs}

Only $72(22.1 \%)$ of the participants knew that HIV can be transmitted via oral sex and $67(20.6 \%)$ knew that anal sex transmits HIV (Table 5). Most participants correctly agreed that HIV infects and damages the CD4 cells $(79.4 \%, n=259)$ and that HIV develops into AIDS $(81.6 \%, n=266)$. Furthermore, $235(72.1 \%)$ knew that HIV is present in semen, blood, vaginal secretions and breast milk. When asked to identify the signs and 
Table 2 General knowledge pertaining to pregnancy and signs of preterm labour $(N=326)$

\begin{tabular}{|c|c|c|c|}
\hline Questions & Correct Answer & Frequencies (n) & Percentages (\%) \\
\hline A pregnant woman must consult a clinician (doctor or midwife/nurse) & True & & \\
\hline True & & 303 & $92.9 \%$ \\
\hline False & & 2 & $0.6 \%$ \\
\hline Do not know & & 21 & $6.4 \%$ \\
\hline $\begin{array}{l}\text { A pregnant woman must consult her clinician (doctor or midwife/nurse) } \\
\text { in the event that she feels unwell, has a fever, and/or experiences an } \\
\text { unusual physical change. }\end{array}$ & True & & \\
\hline True & & 301 & $92.3 \%$ \\
\hline False & & 2 & $0.6 \%$ \\
\hline Do not know & & 23 & $7.1 \%$ \\
\hline
\end{tabular}

To decrease the risk of preterm labour, a pregnant woman should:

All of the above

Attend antenatal care as soon as she knows she is pregnant

Reduce stress

Follow all the healthcare advice given by the doctor or midwife

Eat healthy, nutritious food

All of the above

Do not know

Folic acid is taken by pregnant women because it:

Is essential for the baby's brain and spine development

\section{Prevents nausea}

Is essential for the baby's brain and spine development

Prevents sexually transmitted infections

Helps with the baby's lung development

Helps to reduce lower back pain

Do not know

True

False

False

Do not know

Signs of preterm labour

Persistent cramps and abdominal (stomach pain)

Yes

Yes

No

The release of fluid or blood from the vagina

Yes

$$
\text { Yes }
$$

No

Regular or frequent contractions or changes in the strength or number of contractions

Yes

$$
\begin{aligned}
& \text { Yes } \\
& \text { No }
\end{aligned}
$$


Table 2 General knowledge pertaining to pregnancy and signs of preterm labour $(N=326)$ (Continued)

\begin{tabular}{|c|c|c|c|}
\hline Questions & Correct Answer & Frequencies (n) & Percentages (\%) \\
\hline No & & 302 & $92.6 \%$ \\
\hline Persistent cramps and abdominal (stomach pain) & Yes & & \\
\hline Yes & & 159 & $48.8 \%$ \\
\hline No & & 167 & $51.2 \%$ \\
\hline
\end{tabular}

Table 3 Knowledge regarding alcohol and tobacco use during pregnancy $(N=326)$

\begin{tabular}{|c|c|c|c|}
\hline Questions & Correct Answer & $\begin{array}{l}\text { Frequencies } \\
\text { (n) }\end{array}$ & $\begin{array}{l}\text { Percentages } \\
(\%)\end{array}$ \\
\hline What quantity of alcohol may a pregnant woman consume? & $\begin{array}{l}\text { No quantity of alcohol } \\
\text { is safe during pregnancy. }\end{array}$ & & \\
\hline 1 alcoholic drink a day & & 1 & $0.3 \%$ \\
\hline No quantity of alcohol is safe during pregnancy. & & 302 & $92.6 \%$ \\
\hline Do not know & & 23 & $2.1 \%$ \\
\hline Alcohol consumption during pregnancy results in low birth weight. & Yes & & \\
\hline Yes & & 64 & $19.6 \%$ \\
\hline No & & 262 & $80.4 \%$ \\
\hline Alcohol consumption during pregnancy results in heart defects. & Yes & & \\
\hline Yes & & 67 & $20.6 \%$ \\
\hline No & & 259 & $79.4 \%$ \\
\hline Alcohol consumption during pregnancy results in damage to the unborn baby's liver. & Yes & & \\
\hline Yes & & 118 & $36.2 \%$ \\
\hline No & & 208 & $63.8 \%$ \\
\hline Alcohol consumption during pregnancy results in mental retardation in the unborn baby. & Yes & & \\
\hline Yes & & 209 & $64.1 \%$ \\
\hline No & & 117 & $35.9 \%$ \\
\hline Smoking tobacco during pregnancy results in low birth weight. & Yes & & \\
\hline Yes & & 73 & $22.4 \%$ \\
\hline No & & 253 & $77.6 \%$ \\
\hline Smoking tobacco during pregnancy results in miscarriage. & Yes & & \\
\hline Yes & & 54 & $16.6 \%$ \\
\hline No & & 272 & $83.4 \%$ \\
\hline Smoking tobacco during pregnancy results in preterm labour. & Yes & & \\
\hline Yes & & 22 & $6.7 \%$ \\
\hline No & & 304 & $93.3 \%$ \\
\hline Smoking tobacco during pregnancy results in deformities in the unborn baby. & Yes & & \\
\hline Yes & & 52 & $16 \%$ \\
\hline \multirow[t]{2}{*}{ No } & & 274 & $84 \%$ \\
\hline & No & & \\
\hline Smoking tobacco during pregnancy reduces back pain. & & 2 & $0.6 \%$ \\
\hline Yes & & 2 & $0.6 \%$ \\
\hline No & & 324 & $99.4 \%$ \\
\hline
\end{tabular}


Table 4 Knowledge related to breastfeeding $(N=326)$

\begin{tabular}{|c|c|c|c|}
\hline Questions & $\begin{array}{l}\text { Correct } \\
\text { Answer }\end{array}$ & $\begin{array}{l}\text { Frequencies } \\
\text { (n) }\end{array}$ & $\begin{array}{l}\text { Percentages } \\
(\%)\end{array}$ \\
\hline $\begin{array}{l}\text { Exclusive breastfeeding } \\
\text { is recommended for: }\end{array}$ & 6 months & & \\
\hline 6 weeks & & 3 & $0.9 \%$ \\
\hline 2 months & & 1 & $0.3 \%$ \\
\hline 6 months & & 234 & $71.8 \%$ \\
\hline 8 months & & 13 & $4 \%$ \\
\hline Don't know & & 75 & $23 \%$ \\
\hline $\begin{array}{l}\text { Breastfeeding improves } \\
\text { the immunity of the baby } \\
\text { and protects the baby from } \\
\text { allergies and asthma. }\end{array}$ & True & & \\
\hline True & & 257 & $78.8 \%$ \\
\hline False & & 8 & $2.5 \%$ \\
\hline Do not know & & 61 & $18.7 \%$ \\
\hline $\begin{array}{l}\text { A breast-fed baby has a lower } \\
\text { risk of obesity and diabetes. }\end{array}$ & True & & \\
\hline True & & 190 & $58.3 \%$ \\
\hline False & & 23 & $7.1 \%$ \\
\hline Do not know & & 113 & $34.7 \%$ \\
\hline $\begin{array}{l}\text { Breastfeeding is more time } \\
\text { consuming than bottle feeding. }\end{array}$ & False & & \\
\hline True & & 130 & $39.3 \%$ \\
\hline False & & 68 & $20.9 \%$ \\
\hline Do not know & & 128 & $39.3 \%$ \\
\hline $\begin{array}{l}\text { Breast-fed babies have fewer } \\
\text { dental cavities (i.e., problems } \\
\text { with tooth decay). }\end{array}$ & True & & \\
\hline True & & 193 & $59.2 \%$ \\
\hline False & & 31 & $9.5 \%$ \\
\hline Do not know & & 102 & $31.3 \%$ \\
\hline $\begin{array}{l}\text { Drugs and alcohol can be } \\
\text { passed through breast milk } \\
\text { to the baby. }\end{array}$ & True & & \\
\hline True & & 200 & $61.3 \%$ \\
\hline False & & 25 & $7.7 \%$ \\
\hline Do not know & & 101 & $31 \%$ \\
\hline
\end{tabular}

symptoms related to AIDS, overall, a large percentage of the participants was able to identify rapid weight loss (80.1\%, $n=261)$, extreme weakness $(75.2 \%, n=245)$, chronic diarrhoea $(62.6 \%, n=204)$, white sores in the mouth $(76.4 \%, n=249)$, and sores in the genital region $(66 \%, n=215)$ as indicators.

A low percentage of participants was able to identify Gonorrhoea (24.5\%, $n=80$ ), Syphilis (15\%, $n=49)$, Chlamydia $(3.7 \%, n=12)$ and Genital Herpes $(15.6 \%, n=51)$ as STIs (Table 5). However, when assessing the knowledge of the signs and symptoms of STIs, most participants were able to correctly identify genital sores (57.1\%, $n=186)$, burning urination $(54.9 \%, n=179)$, discharge from the vagina $(65.6 \%, n=214)$, and discharge from the penis $(59.8 \%, n=195)$ as symptoms.

The common prevention methods for HIV and STIs that were identified included condom use $(92.6 \%, n=$ $302)$, being faithful to one partner $(63.8 \%, n=208)$, and refusal to share needles $(67.2 \%, n=219)$. Only $163(50 \%)$ agreed that abstaining from sexual intercourse can prevent HIV and STIs. Twenty-five (7.7\%) participants incorrectly thought that birth control pills can prevent HIV and STIs. One hundred and five (66\%) of the participants correctly agreed that all sexually active women must have an annual pap smear. Most participants $(70.2 \%, n=229)$ knew that a pregnant woman who is infected with HIV and STIs can transmit these diseases to her unborn child.

\section{Personal attitudes towards sexuality and reproductive health}

Of the 326 participants, 79 (24.2\%) agreed that sex before marriage is acceptable whereas 87 (26.7\%) agreed that abstaining from sex is difficult during adolescence (Table 6). Only sixty-one (18.7\%) thought that a female who remains a virgin during her adolescent years is oldfashioned. Fifty- three (16.3\%) agreed that using a condom during sexual intercourse reduces sexual pleasure, while 101 (30\%) agreed that the use of contraceptives causes sterility in women. Furthermore, 79 (23.9\%) agreed that they would be too embarrassed to buy or procure condoms and $52(16 \%)$ agreed that their partners would reject them if they asked them to use a condom. The majority of the participants $(86.8 \%, n=283)$ agreed that family planning services can help prevent an unwanted pregnancy. Overall, 216 (66.3\%) agreed that females are responsible for protection during sexual intercourse.

\section{Peer influence}

Table 6 shows that 231 (70.9\%) of the participants disagreed that their friends believed in waiting for marriage to have sex. Furthermore, 176 (54\%) disagreed that their friends believed in using condoms. Of the 326 participants, only 101 (31.9\%) stated that none of their friends were adolescent mothers.

\section{Categorical variables included in the regression models}

The following categorical variables were included in the regression models: repeat adolescent pregnancy, highest education level, the participants' mothers' marital status, and answering the pregnancy, HIV/AIDS and STI questions correctly. The frequency distributions of these categorical variables can be found in Table 1. Overall, only $143(43.9 \%)$ participants answered $50 \%$ or more of the knowledge questions correctly while 183 (56.1\%) 
Table 5 Knowledge regarding HIV/AIDS and STIs

$(N=326)$

\begin{tabular}{|c|c|c|c|c|c|c|c|}
\hline & \\
\hline Questions & $\begin{array}{l}\text { Correct } \\
\text { Answer }\end{array}$ & $\begin{array}{l}\text { Frequencies } \\
\text { (n) }\end{array}$ & $\begin{array}{l}\text { Percentages } \\
(\%)\end{array}$ & Questions & $\begin{array}{l}\text { Correct } \\
\text { Answer }\end{array}$ & $\begin{array}{l}\text { Frequencies } \\
\text { (n) }\end{array}$ & $\begin{array}{l}\text { Percentages } \\
(\%)\end{array}$ \\
\hline \multirow{2}{*}{$\begin{array}{l}\text { HIV is known as Human } \\
\text { Immunodeficiency Virus. }\end{array}$} & \multirow[t]{5}{*}{ True } & & & Yes & & 51 & $15.6 \%$ \\
\hline & & & & No & & 275 & $84.4 \%$ \\
\hline True & & 266 & $81.6 \%$ & \multirow{3}{*}{$\begin{array}{l}\text { Genital sores are } \\
\text { associated with the } \\
\text { signs and symptoms of } \\
\text { sexually transmitted infections. }\end{array}$} & \multirow[t]{3}{*}{ Yes } & & \\
\hline False & & 5 & $1.5 \%$ & & & & \\
\hline Do not know & & 55 & $16.9 \%$ & & & & \\
\hline $\begin{array}{l}\text { HIV can be transmitted } \\
\text { through oral sex. }\end{array}$ & \multirow[t]{3}{*}{ Yes } & & & Yes & & 186 & $57.1 \%$ \\
\hline 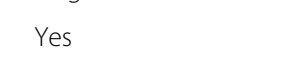 & & 72 & $22.1 \%$ & No & & 140 & $42.9 \%$ \\
\hline No & & 254 & $77.9 \%$ & \multirow{2}{*}{$\begin{array}{l}\text { Burning during urination } \\
\text { is associated with the signs } \\
\text { and symptoms of sexually } \\
\text { transmitted infections. }\end{array}$} & \multirow[t]{2}{*}{ Yes } & & \\
\hline $\begin{array}{l}\text { HIV can be transmitted } \\
\text { through vaginal sex. }\end{array}$ & \multirow[t]{3}{*}{ Yes } & & & & & & \\
\hline Yes & & 233 & $71.5 \%$ & Yes & & 179 & $54.9 \%$ \\
\hline No & & 93 & $28.5 \%$ & No & & 147 & $45.1 \%$ \\
\hline $\begin{array}{l}\text { HIV can be transmitted } \\
\text { through anal sex. }\end{array}$ & \multirow[t]{3}{*}{ Yes } & & & \multirow{2}{*}{$\begin{array}{l}\text { Discharge from the vagina } \\
\text { is associated with the signs } \\
\text { and symptoms of sexually } \\
\text { transmitted infections. }\end{array}$} & \multirow[t]{3}{*}{ Yes } & & \\
\hline Yes & & 67 & $20.6 \%$ & & & & \\
\hline No & & 259 & $79.4 \%$ & Yes & & 214 & $65.6 \%$ \\
\hline $\begin{array}{l}\text { HIV infects and damages } \\
\text { CD4 helper cells. }\end{array}$ & \multirow[t]{4}{*}{ True } & & & No & & 112 & $34.4 \%$ \\
\hline True & & 259 & $79.4 \%$ & \multirow{3}{*}{$\begin{array}{l}\text { Discharge from the penis } \\
\text { is associated with the signs } \\
\text { and symptoms of sexually } \\
\text { transmitted infections. }\end{array}$} & \multirow[t]{3}{*}{ Yes } & & \\
\hline False & & 1 & $0.3 \%$ & & & & \\
\hline Do not know & & 66 & $20.2 \%$ & & & & \\
\hline \multirow[t]{2}{*}{ HIV develops into AIDS. } & \multirow[t]{2}{*}{ True } & & & Yes & & 195 & $59.8 \%$ \\
\hline & & 266 & $816 \%$ & No & & 131 & $40.2 \%$ \\
\hline
\end{tabular}

$3 \quad 0.9 \%$

$57 \quad 17.5 \%$

Do not know

HIV is present in semen, blood, vaginal secretions and breast milk.

True
False

Do not know

Gonorrhoea is a sexually transmitted infection.

Yes
No
Syphilis is a sexually
transmitted infection.
Yes
No

Chlymydia is a sexually transmitted infection.

$$
\text { Yes }
$$$$
\text { No }
$$

Genital Herpes is a sexually transmitted infection.
Table 5 Knowledge regarding HIV/AIDS and STIS $(N=326)$ (Continued)

answered less than $50 \%$ of the knowledge questions correctly.

\section{Bivariate analysis}

As shown in Table 7, there was no relationship between answering the pregnancy and HIV/STI knowledge questions correctly and having a repeat adolescent pregnancy. Almost equal proportions of the participants with and without repeated pregnancies answered $50 \%$ or more questions correctly. Age was positively associated with adolescent repeat pregnancies whereby older participants had higher repeat pregnancies than their younger counterparts $(p<0.0001)$. The participants with a secondary level of education had fewer repeat pregnancies indicating that a higher education level was a protective factor against repeat pregnancies $(P<0.0001)$.

\section{Logistic regression analysis}

Logistic regression was used to construct models. In each model, the outcome variable (adolescent repeat pregnancies) was regressed upon a primary 'exposure of interest'. The exposure variables were age, education level, participants' mothers' marital status, and answering $50 \%$ or more of the questions correctly. The separate 
Table 6 Personal attitudes and peer influences regarding sexuality and reproductive health $(N=326)$

\begin{tabular}{lcl}
\hline Personal attitude statements & Frequencies $(\mathrm{n})$ & Percentages (\%) \\
\hline Sex before marriage is acceptable. & \\
Agree & 79 & $24.2 \%$ \\
Disagree & 233 & $71.5 \%$ \\
Strongly disagree & 14 & $4.3 \%$
\end{tabular}

For a woman, having multiple sex partners is an indication of her attractiveness.

$\begin{array}{lll}\text { Agree } & 10 & 3.1 \% \\ \text { Disagree } & 240 & 73.6 \% \\ \text { Strongly disagree } & 76 & 23.3 \%\end{array}$

It is important for a man to have multiple sex partners to prove his manhood.

$\begin{array}{lll}\text { Agree } & 6 & 1.8 \% \\ \text { Strongly Agree } & 1 & 0.3 \% \\ \text { Disagree } & 142 & 43.6 \% \\ \text { Strongly disagree } & 177 & 54.3 \%\end{array}$

A female who remains a virgin during her adolescence is old-fashioned.

$\begin{array}{lll}\text { Agree } & 61 & 18.7 \% \\ \text { Strongly agree } & 1 & 0.3 \% \\ \text { Disagree } & 242 & 74.2 \% \\ \text { Strongly disagree } & 22 & 6.7 \%\end{array}$

Having a baby at an early age is a sign of maturity.

$\begin{array}{lll}\text { Agree } & 43 & 13.2 \% \\ \text { Strongly agree } & 1 & 0.3 \% \\ \text { Disagree } & 272 & 83.4 \% \\ \text { Strongly disagree } & 10 & 3.1 \%\end{array}$

Abstaining from sex is difficult during adolescence.

$\begin{array}{lll}\text { Agree } & 87 & 26.7 \% \\ \text { Strongly agree } & 2 & 0.6 \% \\ \text { Disagree } & 236 & 72.4 \% \\ \text { Strongly disagree } & 1 & 0.3 \%\end{array}$

Using a condom during sexual intercourse reduces sexual pleasure.

$\begin{array}{lll}\text { Agree } & 53 & 16.3 \% \\ \text { Strongly agree } & 2 & 0.6 \% \\ \text { Disagree } & 265 & 265(81.3 \%) \\ \text { Strongly disagree } & 6 & 6(1.8 \%)\end{array}$

The use of contraceptives cause sterility in women.

$\begin{array}{lll}\text { Agree } & 101 & 31 \% \\ \text { Strongly agree } & 1 & 0.3 \% \\ \text { Disagree } & 221 & 67.8 \% \\ \text { Strongly disagree } & 3 & 0.9 \%\end{array}$

Family planning services can prevent an unwanted pregnancy.

$\begin{array}{lll}\text { Agree } & 283 & 86.8 \% \\ \text { Strongly Agree } & 4 & 1.2 \% \\ \text { Disagree } & 39 & 12 \%\end{array}$

Table 6 Personal attitudes and peer influences regarding sexuality and reproductive health $(N=326)$ (Continued)

\begin{tabular}{lcl}
\hline Personal attitude statements & Frequencies $(\mathrm{n})$ & Percentages (\%) \\
\hline I would be too embarrassed to buy or find condoms. \\
Agree & 78 & $23.9 \%$ \\
Strongly agree & 3 & $0.9 \%$ \\
Disagree & 240 & $73.6 \%$ \\
Strongly disagree & 5 & $1.5 \%$
\end{tabular}

My partner would reject me if I asked him to use a condom.

$\begin{array}{lll}\text { Agree } & 53 & 16 \% \\ \text { Strongly agree } & 1 & 0.3 \% \\ \text { Disagree } & 267 & 81.9 \% \\ \text { Strongly disagree } & 6 & 1.8 \%\end{array}$

Females are responsible for protection during sexual intercourse.

$\begin{array}{lll}\text { Agree } & 216 & 66.3 \% \\ \text { Strongly agree } & 2 & 0.6 \% \\ \text { Disagree } & 106 & 32.5 \% \\ \text { Strongly disagree } & 2 & 0.6 \% \\ \text { Peer influence statements } & \text { Response (n) } & \text { Percentage (\%) }\end{array}$

Most of my friends believe in waiting for marriage to have sex.

$\begin{array}{lll}\text { Agree } & 76 & 23.3 \% \\ \text { Strongly agree } & 1 & 0.3 \% \\ \text { Disagree } & 231 & 70.9 \% \\ \text { Strongly disagree } & 18 & 5.5 \%\end{array}$

Most of my friends do not believe in using contraception.

$\begin{array}{lll}\text { Agree } & 144 & 44.2 \% \\ \text { Strongly agree } & 5 & 1.5 \% \\ \text { Disagree } & 176 & 54 \% \\ \text { Strongly disagree } & 1 & 0.3 \%\end{array}$

Most of friends do not believe in using condoms.

$\begin{array}{lll}\text { Agree } & 124 & 38 \% \\ \text { Strongly agree } & 5 & 1.5 \% \\ \text { Disagree } & 195 & 59.8 \% \\ \text { Strongly disagree } & 2 & 0.6 \%\end{array}$

How many of your friends are adolescent mothers?

\begin{tabular}{lll} 
Many & 31 & $9.5 \%$ \\
Some & 23 & $7.1 \%$ \\
A few & 164 & $50.3 \%$ \\
None & 104 & $31.9 \%$ \\
Do not know & 4 & $1.2 \%$ \\
\hline
\end{tabular}

univariate models with each of these variables are depicted in Table 8. According to the univariate models, the participants' age, education level and biological mothers' marital status shared a relationship with adolescent repeat pregnancy. A multivariable model regressing adolescent repeat 
Table 7 Bivariate analysis (comparison of model variables for participants who had repeat pregnancies versus those who did not)

\begin{tabular}{|c|c|c|c|}
\hline \multirow[t]{2}{*}{ Variables } & \multicolumn{3}{|c|}{ Adolescent Repeat Pregnancies } \\
\hline & $\begin{array}{l}\text { No } \\
n=261\end{array}$ & $\begin{array}{l}\text { Yes } \\
n=65\end{array}$ & $P$-value* \\
\hline Age (years) & $18.0(17.0-19.0)$ & $19.0(18.0-19.0)$ & $<0.0001$ \\
\hline Mother's Marital Status & & & 0.064 \\
\hline Single & $126(48.3 \%)$ & $21(32.3 \%)$ & \\
\hline Married & $76(29.1 \%)$ & $25(38.5 \%)$ & \\
\hline Other & $59(22.6 \%)$ & 19 (29.2\%) & \\
\hline Highest Education Level & & & $<0.0001$ \\
\hline Primary & $2(0.8 \%)$ & $7(10.8 \%)$ & \\
\hline Junior & $6(2.3 \%)$ & $6(9.2 \%)$ & \\
\hline Secondary & $253(96.9 \%)$ & $52(80.0 \%)$ & \\
\hline $\begin{array}{l}\text { Answered knowledge } \\
\text { questions correctly }\end{array}$ & & & 1.0 \\
\hline $\begin{array}{l}50 \% \text { or more correct } \\
\text { answers }\end{array}$ & $115(44.1 \%)$ & $28(43.1 \%)$ & \\
\hline $\begin{array}{l}\text { Less than } 50 \% \text { correct } \\
\text { answers }\end{array}$ & $146(55.9 \%)$ & 37 (56.9\%) & \\
\hline
\end{tabular}

pregnancies (outcome of interest) on the indicator of answering $50 \%$ or more of the pregnancy, HIV/AIDS and STI questions correctly (exposure of interest) is also depicted in Table 8. This model adjusted for age, education level, and participants' mothers' marital status. For each model, an odds ratio for each of the variables in the model, as well as the $95 \%$ confidence intervals, were produced. In the adjusted model, the indicator for whether or not the participants answered 50\% of the pregnancy, HIV/ AIDS and STI knowledge questions correctly was not significant (adjusted odds ratio [OR] 1.04, 95\%, CI 0.6-1.81, $p=0.8862$ ).

\section{Discussion}

Knowledge plays an important role in facilitating people's access to healthcare [16]. The aim of this study was to determine the knowledge, personal attitudes and peer influences related to pregnancy, sexual and reproductive health among adolescents who attended maternal health services in a district hospital in Ugu, KwaZulu-Natal, South Africa. Although 43.9\% of participants scored > 50\% for the knowledge test on pregnancy, HIV/AIDS and STIs, there are serious gaps in their knowledge of danger signs of pregnancy, anaemia, alcohol and tobacco use during pregnancy and sexually transmitted infections.

In our study, $60.4 \%$ of the participants was able to identify vaginal bleeding as a sign of preterm labour. In reviewing the literature, this is low when compared to 86.0 and $82.2 \%$ who were able to identify vaginal bleeding as a danger sign during pregnancy in studies conducted in Malaysia and Tanzania respectively $[16,17]$. The current study found that only $23.3 \%$ of the participants was able to identify blurred or spotted vision as an abnormal sign during pregnancy in comparison to 47.8 and $39.4 \%$ in studies conducted in Malaysia and Ethiopia respectively $[16,23]$. Prior studies have noted the importance of pregnant women having adequate pregnancy related knowledge to identify the appropriate steps to decrease the risk of preterm labour. In this study, $44.2 \%$ of the participants was able to identify the appropriate steps to decrease the risk of preterm labour. This result is in concordance with the level of pregnancy related knowledge

Table 8 The association between answering 50\% or more of the pregnancy and STI/HIV questions correctly and adolescent repeat pregnancies, adjusting for age, education, and biological mothers' marital status

\begin{tabular}{|c|c|c|c|c|c|c|}
\hline \multirow[t]{2}{*}{ Variables } & \multicolumn{3}{|c|}{ Univariate models } & \multicolumn{3}{|c|}{ Multivariable logistic regression } \\
\hline & OR & $95 \% \mathrm{Cl}$ & $P$ value & $\mathrm{AOR}$ & $95 \% \mathrm{Cl}$ & $P$ value \\
\hline Age & 2.69 & $1.85-4.47$ & 0.0000 & 2.79 & $1.87-4.47$ & 0.0000 \\
\hline \multicolumn{7}{|l|}{ Highest education level } \\
\hline Primary & Ref & & & Ref & & \\
\hline Junior & 0.29 & $0.03-1.8$ & 0.248 & 0.41 & $0.04-3.43$ & 0.4194 \\
\hline Secondary & 0.06 & $0.01-0.25$ & 0.0005 & 0.05 & $0.01-0.24$ & 0.00058 \\
\hline \multicolumn{7}{|l|}{ Mothers' Marital Status } \\
\hline Single & Ref & & & Ref & & \\
\hline Married & 1.97 & $1.04-3.8$ & 0.0392 & 1.77 & $0.86-3.69$ & 0.1207 \\
\hline Other & 1.93 & $0.96-3.87$ & 0.0626 & 1.97 & $0.01-4.3$ & 0.08524 \\
\hline \multicolumn{7}{|l|}{ Answered knowledge questions correctly: } \\
\hline Answered $50 \%$ or more questions correct & Ref & & & Ref & & \\
\hline Answered less than $50 \%$ of answered correctly & 1.04 & $0.6-1.87$ & 0.8862 & 0.81 & $0.44-1.51$ & 0.5022 \\
\hline
\end{tabular}


among pregnant women attending an antenatal clinic in Pune, Maharashstra [24]. The ability of pregnant women to identify the signs of preterm labour is critical if they are to counteract this emergency.

Anaemia is associated with adverse events in pregnancy and is common among pregnant adolescents. [25]. The participants in the current study demonstrated poor knowledge of the signs and symptoms of anaemia. More than half (63.2\%) was not aware that iron deficiency can lead to anaemia. This is in contrast to the findings in Brosankro, Ghana, where only $3 \%$ of the participants in a study, was unaware of the link between iron deficiency and anaemia [26]. In the current study, $59.5 \%$ of the participants could identify only one out of thirteen signs and symptoms of anaemia. Less than half of the participants in this study identified pale lips (31.3\%) and pale finger nails (29.8\%) as symptoms of anaemia. This is low in comparison to $87 \%$ of participants who was aware of this fact in a study in Dahalik, Baghdad [27]. In the current study, $43.3 \%$ of the participants identified preterm delivery and low birth weight as complications of anaemia, in comparison to 25.0 and $11.0 \%$ who respectively correctly identified preterm labour and low birth weight as complications of anaemia in a Ghanaian study [26]. Moreover, knowledge of the benefits of folic acid supplementation and neural tube defects is important, yet this study found that only $35.6 \%$ of the participants knew of the benefits of folic acid for brain and spine development. This was slightly better than the findings of a study conducted in Pakistan, in which only $18.4 \%$ of the participants knew of the importance of folic acid for the unborn foetus [28]. A study conducted in Sudan found that only $8.9 \%$ of 1000 pregnant women knew that folic acid prevented birth defects [25].

Alcohol and tobacco use during pregnancy is detrimental to the health of the unborn child [29]. Persistent tobacco inhalation can cause preterm labour, low birth weight, intra-uterine growth retardation, and spontaneous abortion [30]. It is also related to foetal alcohol syndrome [31]. The prevalence of foetal alcohol spectrum disorder (FASD) in South Africa ranges from 29 to 290 per 1000 live births [32]. Many research studies have focused on the population's knowledge of the harmful effects of smoking and alcohol use among adult women of reproductive age. However, research data of knowledge of this threat among pregnant and parenting adolescent women are limited. This is a matter of grave concern, as this study found that only $19.6 \%$ of the participants knew that alcohol consumption results in low birth weight. A national survey among Australian women aged 18 to 45 years revealed that only $28.5 \%$ knew that drinking alcohol during pregnancy could result in low birth weight [31]. Furthermore, the participants' knowledge of the negative effects of tobacco during pregnancy on the unborn child was poor, as only $22.4,16.6$ and $6.7 \%$ identified that smoking tobacco during pregnancy can result in low birth weight, spontaneous abortion and preterm labour respectively. These findings are low compared to those of a US study among pregnant adolescents and adolescent mothers that found that $79.6,85.3$ and $89.0 \%$ were able to correctly identify that smoking during pregnancy results in low birth weight, spontaneous abortion and preterm labour respectively [33].

In our study, $42.9 \%$ of the participants knew that pesticides should be avoided, compared to $96.0 \%$ who knew this in a survey conducted in Northern Thailand [34]. However, regardless of their high knowledge of the harmful effects of pesticides to the unborn child, $37.0 \%$ of participants in Thailand admitted that they still used pesticides in their homes during pregnancy [34]. The knowledge of the harmful effects of pesticides to the unborn child is of public health importance due to neurodevelopmental toxicity [34]. Cats harbour the protozoan parasite Toxoplasma Gandii in their intestinal tract [35] that causes Toxoplasmosis. Toxoplasmosis infection during pregnancy can cause spontaneous abortion, preterm labour, cerebrospinal fluid abnormalities, retinochoroiditis scarring, and intra-uterine growth retardation [35]. Respectively, only 41.1 and $37.0 \%$ of the participants in this study agreed that playing with cats and cleaning a cat's litter box should be avoided. This rate is low compared to the $77.9 \%$ of participants who correctly indicated that a pregnant woman should avoid cleaning a cat's litter box in a study conducted in the Netherlands [36]. The contrast in these findings could be due to a higher literacy rate and access to antenatal education in the Netherlands.

The World Health Organization recommends exclusive breastfeeding for the first 6 months as a global strategy for infant and young child feeding [37]. Breastfeeding has numerous health benefits for the mother and child. The benefits for the child include reduction of dental cavities, improved immunity, and protection against the risk of diabetes and obesity later in life [38]. Most studies to date have investigated knowledge of breast feeding practices rather than knowledge of the health benefits of breastfeeding. In this study, $71.8 \%$ correctly identified that the recommended period for exclusive breast feeding is 6 months. Similarly, $70.13 \%$ of participants in a study conducted in Croatia identified that exclusive breast feeding is recommended for 6 months [39]. Most of the participants $(78.8 \%)$ in this study agreed that breastfeeding improves the immunity of babies. Although somewhat lower, this finding was high enough to support the $92.9 \%$ of a Croatian study [39].

STIs increase the risk of HIV infection, pelvic inflammatory diseases, life threatening pregnancies, and infertility [40]. Adolescents have a higher risk of STIs than adults [41]. In this study, the participants were unable to 
identify common STIs as only $24.5,15.0$ and $15.6 \%$ were able to identify Gonorrhoea, Syphilis, and Genital Herpes as STIs respectively. These findings are consistent with those of a study conducted in Nigeria where 23.0\% identified Gonorrhoea, 2.8\% identified Syphilis, and 6.5\% identified Genital Herpes as STIs [42]. However, the ability to identify signs and symptoms of STIs was better as most participants were able to correctly identify genital sores $(57.1 \%, n=186)$, burning urination $(54.9 \%$, $n=179)$, discharge from the vagina $(65.6 \%, n=214)$, and discharge from the penis $(59.8 \%, n=195)$ as symptoms of STIs. These response rates were far better than those found by Sharma and Sherkane [40], in whose study only $22.8,41.7$ and $13.9 \%$ identified genital sores, genital discharge and burning urination respectively as signs and symptoms of STIs.

The prevalence of HIV amongst women of reproductive age is high in South Africa [43]. In this study, 70.2\% of the participants was aware that a pregnant woman infected with HIV can transmit this disease to her unborn child, which was high in comparison to the $51.6 \%$ in a study conducted in India [44]. Most participants (92.6\%) in the current study confirmed that condom use can prevent HIV and STIs, in comparison to $55.6 \%$ who had this knowledge during a study conducted in Nepal [45]. With regards to HIV prevention, 7.7\% thought that birth control pills would prevent HIV infection. This is low compared to the $41 \%$ in a study conducted in South Delhi, India, who incorrectly believed that birth control pills would prevent HIV infection [46].

A recent study by Amod et al. explored adolescent mothers' perceptions of the Life Orientation curriculum in Gauteng, South Africa [47]. The participants felt that although sexual health was included in Life Orientation, their teachers were not comfortable to teach them about sex education. Furthermore, the participants reported that learners would laugh during the lesson and this annoyed the teacher. Under these circumstances, the lessons on sexual health would be dismissed. Similarly, a study on learners' experiences of Life Orientation in the NorthWest Province reported that $33.3 \%$ of learners mentioned that sex education was covered in Life Orientation [48]. In this study, $87.7 \%$ mentioned that adolescent pregnancy was covered in Life Orientation, while $77.9 \%$ mentioned that HIV/AIDS was covered in Life Orientation. Contrary to the findings of our study, $33.8 \%$ of the North-West study stated that HIV/AIDS was covered and $22 \%$ stated that adolescent pregnancy was covered in Life Orientation.

On face value, the Life Orientation programme appears encouraging, but the practical implementation of this programme has been plagued by many problems, and thus the limited research that has been done on its efficacy in terms of SRH education should be augmented as a matter of urgency.
Personal attitudes towards sexuality and reproductive health is often under-researched. In this study, only $26.7 \%$ agreed that abstaining from sex is difficult during adolescent years. This suggests that most participants had a positive attitude towards abstinence. Similarly, a study by Masters et al. [49] found that more females than males reported positive attitudes towards abstinence (means 3.6 vs 4.0 on the five-point Likert scale, where a score of 3 was neutral). In the current study, only $16.3 \%$ believed that condoms reduce sexual pleasure during sexual intercourse. During a literature review regarding decision making and condom use among South African women, Mash et al. [50] found that men were more likely to believe that condoms reduce sexual pleasure than women. In a patriarchal society, South African women are disempowered and more likely to please their partners by agreeing not to use condoms during sexual intercourse [50]. Thus gender based power inequalities were clearly voiced when $66.3 \%$ of the participants in this study agreed that it is females who are responsible for protection during sexual intercourse. Furthermore, 23.9\% indicated that they would be too embarrassed to buy or find condoms, which suggests that they were not in a situation to negotiate protective sexual intercourse.

Peer influence is related to sexual risk behaviour and adolescent contraceptive behaviour is also influenced by peer norms. Govender et al. [51] conducted a scoping review and found that adolescents who associated with friends who were adolescent parents were more likely to become adolescent parents themselves. In the current study, $66.8 \%$ of the participants had friends who were adolescent mothers which, based on the former study, may suggest that they might be at risk of engaging in unprotected sexual behaviour as well.

The participants limited knowledge of preterm labour, anaemia, alcohol and tobacco use, and sexually transmitted infections may hamper the Safe Motherhood Initiative. The misconceptions harboured by these adolescents about oral contraception and protection against HIV and STIs also suggest the threat of unsafe sexual practices among young people in the Ugu community. Health education on SRH is an integral part of the Safe Motherhood Initiative that is aimed at educating societies about safe sexual conduct.

The study has several limitations. Firstly, our study was conducted in only one district in KwaZulu-Natal and therefore the findings may only be generalised to the Ugu and similar districts. Moreover, the study did not investigate the participants' sources of pregnancy or information regarding their sexual and reproductive health. Recall bias was likely to have occurred when participants are asked about their past exposures. The use of convenience sampling could have also lead to under-representation or over-representation of particular groups within a sample. 
Although our inclusion criteria stipulated that adolescent girls under the age of 18 years had to obtain parental/legal guardian permission prior to consenting to participate in this study, we report that there were no participants under 18 years who were excluded in the study because parents and legal guardians were available to provide written permission.

\section{Conclusion}

The adolescent participants' knowledge of pregnancy, sexual and reproductive health was deficient in many respects. Our research has shown that, regardless of repeat pregnancies, adolescents were not necessarily better informed about pregnancy, sexual and reproductive health. Thus we conclude that social determinants, modes and platforms regarding the delivery of adolescent sexual and reproductive health education have become more important than ever before. Moving forward, an innovative mode to the delivery of sexual and reproductive health education includes the emerging digital platform $[1,52]$. The digital platform encompasses social media, multimedia and mobile phones which is growing popular among young people. Previous studies in Sub-Saharan Africa have demonstrated the feasibility of using mobile phones to deliver SRH information [53, 54].

Schools can play a role in reducing high risk sexual behaviour, transforming the future and improving the well-being of all adolescents. The role of the education sector is therefore crucial as schools can offer skills based SRH education. Schools are also an ideal social environment that can target the individual, families and societies [15]. The role of the healthcare sector is equally important. Health facilities need to be adolescent or youth friendly with convenient service hours. Healthcare providers also need to provide non-judgemental adolescent SRH education and services. Universal access to SRH as echoed in SDG 3 can only be achieved through intersectoral collaboration. Knowledge through education is likely to ensure that adolescent women are better informed to make appropriate decisions about their health during pregnancy and childbirth.

\section{Additional file}

Additional file 1: Adolescent pregnancy, sexual and reproductive health questionnaire. (DOCX $69 \mathrm{~kb})$

\section{Abbreviations}

AIDS: Acquired Immunodeficiency Syndrome; HIV: Human Immunodeficiency Virus; MMSE: Modified mini mental state exam; SRH: Sexual and Reproductive Health; STI: Sexually transmitted disease

\section{Acknowledgements}

The authors would like to express their sincere thanks to the participants for their participation. The authors acknowledge the contributions of Roxanne Beauclair, the South African Department of Science and Technology/National
Research Foundation (DST/NRF) Centre of Excellence in Epidemiological Modelling and Analysis (SACEMA), Stellenbosch University, South Africa.

\section{Authors' contributions}

DG was a principal investigator, SN was the supervisor, and MT was the cosupervisor. All the authors contributed equally to the preparation of the paper/article. All authors have read and approved the manuscript.

\section{Funding}

The research was supported by the UKZN College of Health Sciences Research Office, the Fogarty International Centre (FIC), NIH Common Fund, Office of Strategic Coordination, Office of the Director (OD/OSC/CF/NIH), Office of AIDS Research, Office of the Director (OAR/NIH), and the National Institute of Mental Health $(\mathrm{NIMH} / \mathrm{NIH})$ of the National Institute of Health under Award Number D43TW010131. The content and comments reflect the views of the authors and do not represent the official views of the National Institute of Health. The funders had no role in the design of the study and collection, analysis, and interpretation of data and in writing the manuscript.

\section{Availability of data and materials}

The data used to elicit the findings of this study are available from the corresponding author upon reasonable request.

\section{Ethics approval and consent to participate}

Ethical clearance to conduct the study was obtained from the Biomedical Research Ethics Committee of the University of KwaZulu-Natal (BE553/16). Institutional approval was granted by the KwaZulu-Natal Department of Health and the Chief Executive Officer of the district hospital to conduct the research. Participation was voluntary and informed consent was granted by all participants. The informed consent was written. Parents' or legal guardians' permission was obtained for each participant under the age of 18 who participated in the study.

\section{Consent for publication}

Not applicable.

\section{Competing interests}

The authors declare that they have no competing interests.

\section{Author details}

${ }^{1}$ KwaZulu-Natal Department of Health, Durban, South Africa. ${ }^{2}$ School of Nursing and Public Health, Discipline of Public Health Medicine, University of KwaZulu-Natal, Durban, South Africa. ${ }^{3}$ Developing Research Innovation Localisation and Leadership (DRILL) Fellow, University of KwaZulu- Natal, Durban, South Africa.

Received: 3 January 2019 Accepted: 26 June 2019

Published online: 11 July 2019

\section{References}

1. Plourde K, Fischer S, Cunningham J, Brady K, Brady K, McCarraher DR. Improving the paradigm of the approach to adolescent sexual and reproductive health. Reprod Health. 2016;13(72) Available from: https://doi. org/10.1186/s12978-016-0191-3.

2. Widman L, Choukas-Bradley S, Helms SW, Prinstein MJ. Adolescent susceptibility to peer influence. J Adolesc Health. 2016;58:323-9.

3. World Health Organization. Adolescents: health risks and solutions. Facts sheet 345. 2018. Available from: http://www.who.int/mediacentre/ factsheets/fs345/en/.

4. Sychareun V, Vongxay $V$, Houaboun $S$, Thammavongsa V, Phummavongsa $P$, Chaleunvong $\mathrm{K}$, et al. Determinants of adolescent pregnancy and access to reproductive and sexual health services for married and unmarried adolescents in rural Lao PDR: a qualitative study. BMC Pregnancy Child Birth. 2018;18(219) Available from: https://doi.org/10.1186/s12884-018-1859-1.

5. Statistics South Africa. Statistical release P0302: mid-year population estimates 2018. Pretoria: STATS SA; 2018. Available from: http://www.statssa. gov.za/publications/P0302/P03022018.pdf.

6. Reddy P, Sewpaul S, Jonas K. Teenage pregnancy in South Africa: reducing prevalence and lowering maternal mortality rates. Pretoria: Human Sciences Research Council; 2016. Available: http://www.hsrc.ac za/en/research-data/view/8117 
7. Baxter M, Moodley D. Improving adolescent maternal health. S Afr Med J. 2015;105(11):948-52.

8. Society for Adolescent Health and Medicine. Sexual and reproductive health care: a position paper of the Society for Adolescent Health and Medicine. J Adolesc Health. 2014;54(1):491-6.

9. Morris JL, Rushwan $\mathrm{H}$. Adolescent sexual and reproductive health: the global challenges. Int J Gynecol Obstet. 2015;131:S40-2.

10. World Health Organization. Sexual health, human rights and the law. World Health Organization. Sexual health, Human rights and the law. Geneva: World Health Organization; 2015.

11. Godwin J, Szabo G, Sass J, Sauvarin J. Righting the mismatch between law, policy and sexual and reproductive health needs of young people in the Asia-Pacific region. Reprod Health Matters. 2014;22(44):137-47 Available from: https://doi.org/10.1016/s0968-8080(14)44808-0.

12. Save the Children. Adolescent sexual and reproductive health. Fact Sheet. 2019. Available from: https:/www.savethechildren.org/us/what-we-do/ global-programs/adolescent-sexual-and-reproductive-health.

13. Kumi-Kyereme A, Awusabo-Asare K, Darteh EKM. Attitudes of gatekeepers towards adolescent sexual and reproductive health in Ghana. J Reprod Health. 2014;18(3):142-53.

14. United Nations Population Fund. Motherhood in Childhood. New York: UNFPA; 2013. Available from: https://www.unfpa.org/EN-SWOP2013.

15. Kosinska M, Chichowska A, Tilioune A. An opportune time to improve sexual and reproductive health of adolescents in the European Region through intersectoral collaboration: EntreNous: The European Magazine for Sexual and Reproductive Health/. Copenhagen: WHO Regional Office for Europe; 2016. p. 12-5.

16. Teng SP, Zuo TC, Jummaat FB, Keng SL. Knowledge of pregnancy danger signs and associated factors among Malaysian women. Br J Midwifery. 2015;23(11):800-6.

17. Mwilike B, Nalwadda G, Kagawa M, Malima K, Mselle L. Knowledge of danger signs during pregnancy and subsequent healthcare seeking actions among women in urban Tanzania: a cross-sectional study. BMC Pregnancy Child Birth. 2018;18(1) Available from: https:/doi.org/10.1186/s12884-017-1628-6.

18. National Department of Health, Republic of South Africa. The 2015 National Antenatal Sentinel HIV and syphilis survey report. Pretoria: National Department of Health; 2017.

19. Rapp SR, Espeland MA, Hogan P, Jones BN, Dugan E. Baseline experiences with modified mini mental state exam: the Women's health initiative memory study (WHIMS). Aging Ment Health. 2003;7(3):217-23 Available from: https://doi.org/10.1080/1360786031000101201.

20. Godin K, Blue S, Bourdages N, Edwards S, Horan M, MacDougall R, et al. Assessing public health prenatal education knowledge: findings from the LDCP healthy pregnancies project. Ontario: Woodstock; 2014.

21. Smith KA, Harrison A. Teachers' attitudes towards adolescent sexuality and life skills education in rural South Africa. Sex Educ. 2013;13(1):68-81.

22. South Africa. Department of basic education. Curriculum and assessment policy statement (CAPS) grade 10-12. Life orientation. Pretoria: DBE; 2011.

23. Mekonnen T, Girmaye B, Taye F. Assessment of knowledge and attitudes towards obstetric danger signs during pregnancy among pregnant mothers attending antenatal care in Mizan Aman public health facilities, bench Maji zone, south West Ethiopia. J Gynecol Womens Health. 2018;11(3) Available from: https://doi.org/10.19080/ JGWH.2018.11.555813.

24. Patel BB, Gurmeet P, Sinalkar DR, Pandya KHP, Mahen A, Singh N. A study of knowledge and practices of antenatal care among pregnant women attending an antenatal clinic at a tertiary care hospital of Pune Maharasthra. Med J DY Patil Univ. 2016;9:354-62.

25. Alsammani MA, Kunna A, Adam EM. Factors associated with folic acid intake among pregnant women in Sudan. East Mediterr Health J. 2017;23(10):662-9.

26. Dwumfoure-Asare B, Kwapong MA. Anaemia awareness, beliefs and practices among pregnant women: a baseline assessment at Brosankro community in Ghana. J Nat Sci Res. 2013;3(15).

27. Thabit MF. Maternal knowledge related to anaemia during pregnancy among a sample of mothers attending primary health care centres, Baghdad. Al Kindy Coll Med J. 2017;13(2):79-84.

28. Shoaib M, Choudry UK, Tariqa S, Siddiqa IA, Khaliq MF, Noorani MM, et al. Folic acid and neural tube defects: knowledge and practices of mothers from Pakistan. J Surg Emerg Med. 2017;1(1). Available: www. imedpub.com/.../folic-acid-and-neural-tube-defects-knowledge-andpractices.
29. Passey ME, Sanson-Fisher RW, D'Este CA, Stirling JM. Tobacco, alcohol and cannabis use during pregnancy: clustering of risks. Drugs Alcohol Depend. 2014;134:44-50.

30. Polen KND, Shandu PK, Honein M, Green KK, Berkowitz J, Jill P, et al. Knowledge and attitudes of adults towards smoking in pregnancy: results from the health styles 2008 survey. Matern Child Health J. 2014:19 Available from: https://doi.org/10.10007/s10995-014-1505-0.

31. Peadon E, Payne J, Henley N, D'Antoine H, Bartu A, O'Leary C, et al. Women's knowledge and attitudes regarding alcohol consumption in pregnancy: a national survey. BMC Public Health. 2010;10(510) Available from: http://www.biomedcentral.com/1471-2458/10/510.

32. Olivier L, Curfs LMG, Viljoen DL. Foetal alcohol spectrum disorders: prevalence rates in South Africa. SAMJ. 2016;106(6):S103-6.

33. Leiner M, Villa $H$, Singh $N$, Medina I, Shirsat P. Pregnant teenagers and teenage mothers: how much they really know about the risks to children's health associated with smoking during and after pregnancy. J Sch Health. 2007;77:101-2.

34. Lorenz AN, Prapamontol T, Narksen W, Srinual N, Barr DB, Riederer AM. Pilot study of pesticide knowledge, attitudes, and practices among pregnant women in northern Thailand. Int J Environ Res Public Health. 2012;9:3365-83.

35. Da Silva SJA, da Graca CFCR, de Aquino DMC, da Silva CN, da Silva MAC, do Desterro SBNM. Knowledge and perceptions of toxoplasmosis among pregnant women and nurses who provide prenatal in primary care. J Sao Paulo Institute Trop Med. 2017;59(e31) Available from: https://doi.org/10. 1590/S1678-9946201759031

36. Pereboom MTR, Mannien J, Spelten ER, Schellevis FG, Hutton EK. Observational study to assess pregnant women's knowledge and behaviour to prevent toxoplasmosis, literiosis and cytomegalovirus. BMC Pregnancy Child Birth. 2013;13(98) Available from: http://www.biomedcentral.com/ 1471-2393/13/98.

37. World Health Organization \& UNICEF. Global strategy for infant and young child feeding. Geneva: WHO; 2003. Available from: https://www.who.int/ maternal_child_adolescent/topics/child/nutrition/global/en/.

38. Intiful F, Osei C, Steel-Dadzie R, Nyarko R, Asante M. Views of first-time expectant mothers on breastfeeding: A study in three health facilities in Accra, Ghana. Advances Public Health. 2017:4894026 Available from: https:// doi.org/10.1155/2017/4894026.

39. CatipovicM, Voskresensky Baricic T, Rokvic S, Grguric J. Adolescents' knowledge of breastfeeding and their intention to breastfeed in the future. Children. 2017;4:51. Available from: https://doi.org/10.3390/children4060051.

40. Sharma P, Sherkhane MS. Knowledge and attitude about sexually transmitted infections among women in reproductive age group residing in urban slums. Int J Community Med Public Health. 2017;4(1):20-4.

41. Hossain M, Mani KKC, Sidik SM, Shahar HK, Islam R. Knowledge and awareness about STDs among women in Bangladesh. BMC Public Health. 2014;14(775) Available from: http://www.biomedcentral.com/ $1471-2458 / 14 / 775$.

42. Amu EO, Adegun PT. Awareness of Sexually transmitted infections among secondary school adolescents in Ado Ekiti, South Western Nigeria. J Sex Transm Dis. 2015:260126 Available from: https:/doi.org/10.1155/2015/260126.

43. Haffejee F, Ports KA, Mosavel M. Knowledge and attitudes about HIV infection and prevention of mother to child transmission of HIV in an urban, low income community in Durban, South Africa: perspectives of residents and healthcare volunteers. Health SA/Gesondheid SA. 2016;21:171-8.

44. Parmar M, Aherwar R, Jawade S. Awareness, knowledge and prevention of mother to child transmission of human immunodeficiency virus in pregnant women: a descriptive study. Int J Reprod Contracept Obstet Gynaecol. 2016;5(7):2215-20.

45. Pandey N. Knowledge of pregnant women regarding HIV/AIDS. J Chitwan Med Coll. 2013;3(3):18-21.

46. McManus A, Dhar L. Study of knowledge, perception and attitude of adolescent girls towards STIs/HIV, safer sex and sex education: a cross sectional survey of urban adolescent school girls in South Delhi, India. BMC Womens Health. 2008;8(12) Available from: http://www.biomedcentral.com/ 1472-6874-8-12.

47. Amod Z, Halana V, Smith N. School-going teenage mothers in an under-resourced community: lived experiences and perceptions of support. J Youth Stud. 2019. Available from. https://doi.org/10.1080/ 13676261.2019.1571177. 
48. Jacobs A. Life orientation as experienced by learners: a qualitative study in north-West Province. S Afr J Educ. 2011;31:212-23.

49. Masters T, Beadnell BA, Morrison DM, Hoppe MJ, Gillmore MR. The opposite of sex? Adolescents' thoughts about abstinence and sex, and their sexual behaviour. Perspect Sex Reprod Health. 2008;40(2):87-93.

50. Mash R, Mash B, de Villiers P. 'Why don't you just use a condom? Understanding the motivational tensions in the minds of south African women. PHCFM. 2010; Available from: https://doi.org/10.4102/phcfm.v2i.79.

51. Govender D, Naidoo S, Taylor M. Scoping review of risk factors of and interventions for adolescent repeat pregnancy: a public health perspective. Afr J Prim Health Care Fam Med. 2018;10(1) Available from: https:/doi.org/ 10.4102/phcfm.v1011.1685.

52. Evalia H, Shikabukha K, Wanjiru M, Westeneng J. Reaching young people through digital platforms: findings of a study of NAYA's field programme: Rugters and NAYA; 2016

53. L'Engle KL, Vahdat HL, Ndakidemi E, Lasway C, Zan T. Evaluating feasibility, reach and potential impact of a text message family planning information service in Tanzania. Contraception. 2013;87:251-6. https://doi.org/10.1016/j. contraception.2012.07.009.25.

54. Vahdat $\mathrm{HL}$, L'Engle KL, Plourde KF, Magaria L, Olawo A. There are some questions you may not ask in a clinic: providing contraception information to young people in Kenya using SMS. Int J Gynaecol Obstet. 2013;123(Suppl 1):e2-6. https://doi.org/10.1016/j.jigo.2013.07.009.

\section{Publisher's Note}

Springer Nature remains neutral with regard to jurisdictional claims in published maps and institutional affiliations.

Ready to submit your research? Choose BMC and benefit from:

- fast, convenient online submission

- thorough peer review by experienced researchers in your field

- rapid publication on acceptance

- support for research data, including large and complex data types

- gold Open Access which fosters wider collaboration and increased citations

- maximum visibility for your research: over $100 \mathrm{M}$ website views per year

At $\mathrm{BMC}$, research is always in progress.

Learn more biomedcentral.com/submissions 